\title{
BIBLE TRANSLATION AND RECONSTRUCTION HERMENEUTICS
}

\author{
Jean-Claude Loba-Mkole \\ University of Pretoria
}

\section{ABSTRACT}

The role that Africa has played in the history of Bible translation since the event of the LXX is impressive. Yet, there is still a lot that Africa can contribute to Bible translation theory and practice. Following a previous study on this topic (LobaMkole 2008), this paper attempts to articulate how African theology of reconstruction can contribute to enhance new ways of understanding and doing Bible translation in Africa. Jesse N. K. Mugambi remains one of the most known proponents of reconstruction theology in Africa. The first section of the present study seeks to appreciate Mugambi's contribution in the light of other similar writings, especially those from Kinshasa school of theology and Charles Villa-Vicencio from South Africa. Generally speaking, reconstruction paradigm is meant to rebuild all sectors of life in Africa, including Church ministries of which Bible translation constitutes an integral part. The second part will point out areas in which reconstruction paradigm is able to contribute specifically in the field of Bible translation.

\section{Introduction}

Jesse N. K. Mugambi remains one of the best known proponents of reconstruction theology in Africa. The first goal of this paper is to appreciate Mugambi's contribution in the light of other similar writings, especially those from the Kinshasa school of theology and Charles Villa-Vicencio. Generally speaking, the reconstruction paradigm is meant to rebuild all sectors of life in Africa, including church ministries of which Bible translation constitutes to be an integral part. That is why the second goal of this study is to show whether reconstruction paradigm is able to contribute anything in the field of Bible translation and whether the latter can enhance the former. Then the paper will first expose some contents of African reconstruction hermeneutics while the second part shall deal with a brief history of Bible translation in Africa, where any contribution 
by reconstruction hermeneutics will be highlighted. Africa is taken in a geographical sense and refers to the land, people or culture of the continent which bears that name. The conclusion will summarise the findings.

\section{Reconstruction Hermeneutics}

Reconstruction Hermeneutics in Africa is most associated with the Kenyan Jesse N. K. Mugambi, the South African Villa-Vicencio, and the Congolese Kä Mana. For some scholars, it represents a new flow of thought which started in 1990 under the patronage of the All Africa Conference of Churches (AACC). It claims to offer an alternative thinking for mobilising resources to rebuild the Post Cold-War Africa, a topic that might not have been adequately addressed by early paradigms such as inculturation and liberation. However, it seems more constructive to consider inculturation, liberation, and reconstruction as particular efforts of articulating contextual theology in Africa. Each of them, and even all of them together, constitutes an unfinished task to the extent that none of them can claim to offer alone the exhaustive and final approach to African reality. Furthermore, all three aim at the same ultimate goal, namely, the betterment of spiritual and social life in Africa. Therefore, it is not surprising to find many aspects of their agenda and expressions overlapping. More interestingly, the Kinshasa school of theology has been wrestling with all three paradigms, even if some scholars may associate Kinshasa with inculturation only. The first section of this part will try to show how the three paradigms are articulated in the Kinshasa school of theology. The second and the third ones will explore how reconstruction theology has been developed by Charles Villa-Vicencio and Jesse N. K. Mugambi respectively.

\subsection{Reconstruction Hermeneutics in the Kinshasa School of Theology}

Kinshasa school of theology refers to a tradition of thought generated among Congolese and other scholars through academic training, teaching, research or pastoral involvement at Catholic Faculties of Kinshasa since its foundation in 1957. It has been focusing on contextual theology with a particular emphasis on inculturation. The school inherited this concept from some immediate pioneers like "La Philosophie Bantue" by Placide Tempels (1948) and from a collective book entitled Des Prêtres noirs s'interrogent (1956). Inculturation generally means a process of gospel incarnation in a culture and the evangelization of the culture or a constructive dialogue between biblical, traditional, and contemporary cultures. "La philosophie Bantue" and Des Prêtres noirs s'interrogent advocated the need for evangelising Africa in a way that both promotes its positive cultural values and discourages only the negative ones, instead of demoting African culture as a whole. For the Kinshasa school of theology, the theological debate that took place in 1960 between Tharcisse Tshibangu (1960:333-46) and Alfred Vanneste (1960:346-52) about the possibility of African theology marked a more academic start of inculturation theology in Africa. In 1961, the Episcopal Conference of DRCongo 
adopted and introduced inculturation as the key pastoral option for the church. This option envisioned the growth of local churches to become self-supportive in terms of staff, theology, liturgy, and funds. Unsurprisingly, such an option certainly triggered a movement of liberation from dependency on external forces in all vital sectors. Consequently, the Kinshasa school of theology has rightly been depicted as a theology of inculturation and promotion-liberation (Ngindu-Mushete 1989:107; Bujo \& IlungaMuya 2003/6:67). More recently, an inculturation-liberation paradigm is being developed with newer insights from biblical exegesis through the methods of inculturation biblical hermeneutics or intercultural exegesis and mediations (Matand 1998:143-67; Cilumba 2001; Loba-Mkole 2005). Though they characterise the Kinshasa school of theology, inculturation and promotion-liberation concerns go beyond this school, as it is evidenced in the works of other African theologians (Bujo \& Ilunga-Muya 2003/6).

Reconstruction hermeneutics in the Kinshasa school of theology emerged with the philosopher, theologian, and catholic priest N. Tshiamalenga (1981:71-80), was relayed by a Pan-African Catholic Church institution, the Symposium of Episcopal Conference of Africa and Madagascar (SECAM: 1985) and was more vividly advocated by the Lutheran theologian Kä Mana (1993; 1994; 2000). Borrowing this concept from K. O. Apel and J. Habermas, Tshiamalenga defines reconstruction as a critical synthesis of various situations put into words, and of a meaningful whole of philosophical texts starting from pre-existing collections. It implies a deconstruction of the received sense and its reconstruction with an enriched sense. Tshiamalenga presents four steps of reconstruction applicable to African philosophy: (1) the choice of topics, (2) faithful and critical reproduction, (3) historical and/or systematic reconstruction, and (4) creative philosophical production. Faithful and critical reproduction refers to a genuine and rationally justified rendering of the collected traditions. Historical and/or systematic reconstruction requires finding a unifying whole, thanks to a judicious choice of one or several operational concepts. Creative philosophical production is achieved as an African philosopher answers universal questions of humanity and its destiny, in consonance with African and global sources. Many philosophers have practiced a similar systemic reconstruction of previous philosophies or traditions. This applies to Plato with the notion of ideas, Aristotle with matter and form, Descartes with evidence, Kant with the transcendental subject, Marx and Engels with the class struggle, Tempels with life-force, and Nyerere with "Ujamaa." Tshiamalenga himself came up with the philosophy of "bisoity," which is a neologism coined from the Lingala word "biso," meaning "we." It underscores the absolute primacy of the "we" over the "I-You." On a global scale, "bisoity" is systematically founded on the philosophy of language (Apel and Habermas), yet it strongly resonates with the African philosophy of solidarity or that of Nyerere's Ujamaa. For Tshiamalenga, this process of semio-pragmatic reconstruction can be extended to African theology, as well. It just requires the latter to integrate the four essential moments in its research endeavour, i.e., selection of topics, faithful and critical restoration, historical and/or systematic reconstruction, and creative theological production. 
Tshiamalenga's philosophical system of bisoity values African traditional ethics, namely that of the Luba ethnic group (Central DRCongo). This ethic is defined in terms of "ethics before God" and "ethics before society". Ethics before God probes the heart, but what offends God is the evil intention rather than the materiality of evil actions. People, however, are more concerned about ethics before society. This ethic is summarised in four great crimes dictated by the ancestors: killing or wounding another, seizing another's goods or wife, eating others by sorcery, and adulterous women (1974:184).

In 1985, SECAM invited Christians to engage in the reconstruction of the continent:

The credibility and possibility of evangelisation will be to the measure of its being in accordance with the legitimate African aspiration to take their destiny into their hands, and to the measure of its being at the disposal of the search for solutions to the problems of this continent and its reconstruction (SECAM 1985: \# 77).

Kä Mana (1993:45) criticises the inculturation-liberation theology as inadequate for post-colonial Africa, and embraces the reconstruction model, as proposed by AACC. He does not refer either to Tshiamalenga or to SECAM. He credits Jose B. Chipenda and André Karamaga as the initiators of reconstruction theology before AACC could adopt it in 1990. For Kä Mana, this paradigm was timely, since after the failure of thirty years of independence, Africa needed to reconstruct sustainable economies, human policies, creative societies, and cultures capable of historical undertakings.

Kä Mana (1993:117-8; 1994:216-22) posits four ethical and practical tasks of reconstruction theology. These include incarnation (being immerged in the life of African societies), question time (contesting everything which alienates human dignity), liberation (freeing the imagination to overcome psychological illness, political inability, cultural dreariness, and economic anguish), and innovation (planting the seed of the Kingdom of God on the political, economic, social, spiritual, and moral sites of the continent). More interestingly, Kä Mana (1993:197) recognises that liberation, inculturation, and reconstruction are three inseparable parts of the same life experience. While overloaded by sorrowful life experiences, Africans dream about life in abundance promised by Jesus of Nazareth. The project of reconstructing Africa finds its strongest biblical foundation in John 10:10 (Kä Mana 1994:101). Jesus of Nazareth and Christology are at the heart of reconstruction theology. Jesus is portrayed not only as the founder of Christian faith, but also the very person who constitutes the radical logic of love. Because of him, reconstruction's ethics implies a fight for, in, and by love. This is manifested by the logic of giving and sharing, creating the other in his/her very human image, making concrete solidarities based on human dignity, and allowing a new world in which all are one by love (1993: 191-3).

Even if Kä Mana does not make use of insights from Tshiamalenga, he ends up doing what the latter has recommended for African theology, namely, deconstructing and reconstructing. As Valentin Dedji (2003:141) puts it: 
Not only he [Kä Mana] is prompt at deconstructing most of theological, ideological, and social theories that have hitherto characterised intellectual debates in Africa, but he also suggests alternative patterns of creative thought and reconstructive action. He exemplifies the principle according to which, in order to reconstruct, one must deconstruct.

\subsection{Villa-Vicencio and Theology of Reconstruction}

In 1992, Charles Villa-Vicencio published a book entitled $A$ Theology of Reconstruction: Nation-Building and Human Rights. This book investigates the implications of transforming liberation theology into a theology of reconstruction. The role of reconstructive theology is examined within a context of nation-building, weight of dead generations, rule of law and values, human rights, politics, economy, and the right to believe.

For Villa-Vicencio, the themes of economic justice and the spiritual empowerment of the poor continue to be relevant to the period of reconstruction in South Africa, Eastern Europe, Latin America, and elsewhere. In addition to the particular demands of each context, one needs to be aware of four historical shifts that have taken place within the global context:

The failure of the economic and political structures of Eastern Europe, the collapse of a widespread belief in utopian socialist ideals in the Third World countries, the failure of Westernbased capitalism to meet the needs of the poor, a new-found appreciation that even under the most adverse conditions, the poor rise in rebellion in demand of their rights (Villa-Vicencio 1999:163).

It is within this context that the empowerment of the poor becomes a key concept of Villa-Vicencio's reconstruction agenda. He requests theologians to be concerned about human rights, promoting democracy in terms of the "recognition of difference and the right of dissent," as well as being involved in "matters of constitutionalism, the rule of law, human rights and free elections as a basis for addressing the economic problems of the poor" (Villa-Vicencio 1999:168).

Villa-Vicencio (1999:164-7) offers eight theological observations for the church to consider promoting as an alternative or just economy that favours the poor.

1. Theology as a discourse about the well-being of God's creation, which implies due respect of human dignity, solidarity and natural environment: neither a human being nor a natural order must be subjugated to unnecessary exploitation.

2. Commitment to a balanced budget, although one that favours the poor, in order to materialise theological ideals of the alternative economy.

3. The church to work with concerned economists, political activists, and exploited poor in order to redress situations that benefit the rich and impoverish the poor (trans-national corporations, monopoly businesses, labour-saving technology, etc).

4. The church to ask anew whether the concerns of the poor are being promoted within any particular economic order. 
5. Supporting specific models of economic growth and distribution to the benefit of the poor and disadvantaged, encouraging small business initiatives, informal trading and agricultural cooperatives, and protecting them from being swallowed up by big companies.

6. Addressing seriously the issues of environmental pollution by the industrial economy (Mugambi \& Vähäkangas 2001; RAT 2004).

7. The church to discern the practical implications of theological work that supports the struggle for a just economic system within the Bible. The biblical God takes sides with the poor and the destitute (Lev 25; Exod, Amos; Matt 25:31-46; Luke 1:46-56; etc).

8. The church to take note of the legitimate objection of economists that "theology does not produce grain, nor does it build houses!" However, theology has to play its role of bringing forth basic liberating biblical traditions in the struggle for a just economic system.

In Villa-Vicencio's reconstruction theology, "ubuntu" and freedom are regarded as ethical values. Ubuntu (humaneness) is a key category of African traditions, where it is understood as the organic wholeness of humanity - a wholeness realised in and through other people. This notion, in the view of Villa-Vicencio, is enshrined in the Xhosa proverb: umuntu ngumuntu ngabantu (a person is a person through persons). He argues that ubuntu "involves the realisation of that for better and worse we are shaped by a host of others with whom we share our lives". Ubuntu is a set of meaningful relationships that are cherished by traditional African culture, i.e., kinship by blood, by marriage, or even by association (Villa-Vicencio 1999:169; Mugambi \& Smit 2004:83-111). Freedom is a basic human value, which is not achieved in a day, or once and forever. It is rather an unfinished process (Villa-Vicencio 1999:171). Nelson Mandela (1994:616-7), the South African icon of freedom fighters, acknowledges that even his liberation out of jail was only a first step of a longer and more difficult journey.

\subsection{Mugambi and Reconstruction Hermeneutics}

Following his article published in 1991, Jesse N. K. Mugambi has elaborated on reconstruction more remarkably since 1995 and onwards (2003). This paradigm was proposed as a new paradigm for African Christian theology and agreed upon during the General Committee of AACC (1991) held in Nairobi early in 1990. For Mugambi (1995:2), this concept has a multi-disciplinary appeal, as it should be of interest to sociologists, economists, and political scientists. More interestingly, he finds that reconstruction should be of interest to African theologians of all doctrinal persuasions, given that the task of social reconstruction cannot be restricted to religious denominational confines. According to him, the concept of liberation "has been closely associated with Anglophone Protestant theologians, having been first popularised by Latin American and African-American theologians". Inculturation "has been associated with some African 
Catholic theologians, having been first popularised by Catholic missionary scholars, notably Aylward Shorter" (Mugambi 1995:2). Mugambi's reconstruction theology or, rather, Christian theology of social reconstruction targets different levels, which include personal, cultural, ecclesiastical, political, economic, aesthetic, moral, and theological (Mugambi 1995:15-7; 2003:36-60). Methodologically, Mugambi's reconstructive theology operates by treading "across four modes of intellectual activity - descriptive, prescriptive, prospective and postulative" (Mugambi 2003:218).

For Mugambi (1995:xv) the "New World Order" will require a new understanding of the church or a new ecumenism and a new corresponding theology that "should be reconstructive rather than destructive . . . inclusive rather than competitive...". Mugambi (1995:13) acknowledges that the notion of construction and reconstruction is inspired by engineering and the social sciences. He nevertheless attempts to articulate it as a theological paradigm. Nehemiah in the book that bears his name and Jesus in Matthew 5-7 are viewed as exemplary figures in "reconstructive theological texts". According to Mugambi (2003:74), the task or ethics of reconstruction requires the input of all members of the community. Professionals and unskilled members are all invited to voluntarily place their expertise or labour where it is needed in the reconstruction process, for the common good of the whole community. In other words, each one is responsible to bring his or her contribution to the edification of better church and civil communities in Africa. If he has been accused of lacking originality, Mugambi has the merit of stressing the necessity of building a solid foundation for a new ecumenism that would give priority to cooperation and amiability over the old antagonism among African Christian churches (Dedji 2003:87).

Some biblical scholars have started to embrace the reconstruction paradigm and use it as a biblical hermeneutical tool. Manus offers a reconstructive re-reading of Mark 11:15-19, which reports the story of the cleansing of the temple. His model of reconstructive reading proceeds by establishing the social-historical context of the story, analyses the Markan text, as well as the Synoptic-Johannine revision of the text. He comes up with some interpretations grounded in previous analysis. He concludes that Jesus' action challenges us to reconstruct ourselves first and foremost; and then to go out into the larger society as "salt of the earth and light of the world". This conclusion is based on the understanding of Mark 11:11-19 which ultimately portrays Jesus as the Reconstructor: "the reconstructor of the degradation the national religious and cultic center had fallen into," and "the reconstructor of the spiritual wellbeing of the temple worshippers" (Manus 2003:116). Manus (2003:106) is the first African scholar who has ever attempted to "demonstrate how Mugambi's theology of reconstruction can be further strengthened, via intercultural hermeneutics" (i.e., biblical exegesis). It is strange that Mugambi does not refer to such an excellent and supportive move in his major subsequent publication. Mugambi (2003:150-53) has a section on "Reconstructive Biblical hermeneutics in Africa," but fails to mention Manus' work or any other relevant publication. Nevertheless, inspired both by Mugambi and Manus, but each in his own ways, the present work offers another possibility of enhancing reconstruction 
hermeneutics with a contribution of biblical study, using, namely, a Bible translation approach.

In his turn, Farisani (2004:56-82) embarks on reading Romans 12:1-2 in the light of the reconstruction paradigm. His model of reconstruction hermeneutics seems to align views of some exegetes regarding Romans 12:1-2 and different levels of reconstruction as defined by Mugambi in 1995. On a concluding note, he credits Mugambi and others for having perceived the change in the African situation and the relevance of the reconstruction paradigm to respond to issues of social transformation. Farisani seems to have correctly understood Mugambi's views about inculturation/liberation versus reconstruction. The latter emerged within the context of post-colonial social reconstruction while the former is related to the context of colonialism. As a result, the focus of inculturaltion theology would be to make the gospel relevant to African cultures, while the focus of liberation would be to uplift the poor out of oppression. Reconstruction theology "suggests proactive actions that would denounce poverty and "remove poverty from the society" (Farisani 2004:78).

In a nutshell, reconstruction is a hermeneutical paradigm that has been proposed and supported not only by individuals (Tshimalanga, Kä Mana, Villa-Vicencio, and Mugambi), but also by both Catholic and Protestant communities (SECAM, AACC).

In addition to the four individual pioneers who support this new paradigm on philosophical and theological grounds, it is encouraging to notice that biblical scholars like Manus and Farisani have embarked on the same agenda. What can Bible translations in Africa benefit from this move or how can they offer to strengthen it?

\section{Bible Translation in Africa}

In order to get a proper picture of what Bible translation in Africa is capable of receiving from reconstruction hermeneutics or how it may enhance the latter, it is important to understand the history of Scripture versions on the continent. Furthermore, since this article is probably the first work to link reconstruction hermeneutics and Bible translation study, a historical approach seems to be the best. Before engaging in this approach, I will give a brief overview of the meaning of Bible translation.

Any translation or translated text (including Bible versions) presupposes different frames of reference: components of communication (participants, texts, and media), cognitive frames (signs, gestures, words, expressions, pictures, etc), socio-cultural frames (religious rites, social behaviours, cultural values, etc.), and organisational frames (church communities, Bible translation agencies, political powers). It seems appropriate to define translation as a complex mediated act of communication (Wilt 2003:27-80; Wendland 2004:84) or an act of intercultural mediation (Cronin 2003:124; Loba 2005:19; 2008:179-80). There are many approaches to translation, ranging from literalist, functionalist, descriptive, text-linguistic, relevance, interpretive, comparative, professional, and literary-rhetorical (Wendland 2004:47-80). For practical reasons, I stick to the definition of Bible translation as consisting of reproducing in the receptor 
language the closest natural equivalent of the source-language message, in terms of meaning and style (Nida \& Taber 1969:12). Nida's functionalist approach is the mostwidely known in Africa and beyond. Yet, this approach still needs to be enhanced and fully applied to various African translation projects that claim to follow this method. However, examining the history of Bible translation in Africa may provide some useful insights, which can help the reader appreciate the need for quality improvement. The following section will examine this history in two sections: the period of early translations and that of modern translations.

\subsection{Early Translations (Third Century BC-Sixth Century AD)}

The history of Bible translation in Africa goes back to the third century BC, when the Hebrew Bible was translated into Greek in Alexandria (Egypt). This famous translation is known as the Septuagint (LXX), referring to the seventy elders who were commissioned to carry it out. However, the Letter of Aristeas, followed by Josephus (Ant. 12.2.13), talks about seventy-two elders (six representing each of the twelve tribes of Israel). Some church fathers like St Augustine and St Jerome mention seventy while one Jewish source (Sopherim, c.i) indicates five elders. These numbers are all symbolically important. Seventy-two represents a great deal of each Israelite tribe, seventy refers to Israel through the elders who accompanied Moses to receive God's commandments on Mount Sinai, and five reminds one of the books of the Pentateuch or Torah at large. Though working on African soil, it is obvious that the translators of the LXX were not Africans, nor was the source language (Hebrew) neither the target language (Greek). Africans from Alexandria could nevertheless benefit from this translation, as it was placed in the Alexandrian royal library for public use, and later on was spread among early Christian communities of North Africa.

Before the end of the second century AD, people from North Africa were also interacting with Scriptures through the Old Latin translation (Vetus Itala), which was based on LXX and Greek manuscripts of the NT. In the beginning, Christian literature in Latin flourished in North Africa with Clement of Alexandria (150-216), Tertullian (155-230), Origin (185-254), Athanasius of Alexandria (293-373), Augustine of Hippo (354-430), and many more. Biblical quotations from these African church fathers and ecclesiastic writers serve as important sources not only in studying Bible translation techniques but also in reconstructing the earliest manuscripts of the NT. These quotations are part of the "reconstructed text of the New Testament" (Petzer 1994:11) or even "absolutely vital for any reconsideration of the history of the transmission of the New Testament text" (Ehrman 1994:134). As far as textual criticism is concerned, what the Old Latin and Patristic quotations represent for the transmission of the NT text echoes what LXX means for the OT text:

Many manuscripts of the Latin Bible are of specific importance because they often testify to a text older than many surviving Greek manuscripts (in the case of the New Testament) or of the Masoretic or Septuagint text (for the Old Testament) (Bogaert 1996:426; see also Loba-Mkole 1999:115). 
For Johan Lust, "even after the discovery of the Dead Sea scrolls, the Septuagint, ... remains one of the most important though indirect witness to the Hebrew text" (Lust 2002:17-8; Cook 2005:539). Even St Jerome's Vulgate (fourth - fifth century AD) in some few cases seems to depend on the Old Latin and LXX more than on the Hebrew Bible.

The very first African Bible translations in terms of language and personnel could be the Egyptian or Coptic versions. It is known that the use of Greek was common for the first Christians of Lower Egypt, but the natives spoke Coptic, namely, Bohairic, Sahidic, Akhmimic, Fayûmic, and other dialects. Bible translations in these dialects, if not all, date back to the third or fourth century AD. The most important Coptic Bible versions are preserved in Bohairic or Memphite (spoken at Memphis and Alexandria) and Sahidic (used in upper Thebais). Bohairic has been the standard text of the church in Egypt since the eleventh or twelfth century. Some large fragments of biblical texts have been preserved in Sahidic, as well as the manuscripts of the Gnostic library of NagHammadi. Few fragments have been found in Akhmimic (e.g., John's Gospel, dating from the fourth century) and Fayûmic (e.g., Acts 7:14-28; 9:28-39).

If biblical texts exist as translated or reconstructed texts, Africa has played a significant role in both processes. It provided a location (Alexandria) for translating the Hebrew Bible as well as scholars who through their Latin or Coptic mediations have offered tremendous contributions in the critical transmission and reconstruction of the Bible. In addition, some manuscripts of Alexandrian type (Codices Sinaiticus, Vaticanus, and Alexandrianus, all dating from the fourth century AD) are considered to be witnesses of the first order (category I) from the perspective of NT external criticism. Furthermore, it is worth mentioning that the papyri, some of which represent the earliest witnesses of the NT since the period before $150 \mathrm{AD}$, are all Egyptian products.

Other early translations in Africa include Ethiopic versions (fourth — sixth century $\mathrm{AD})$. The Bible was translated from the LXX into Ethiopic or Ge' ez by various hands. In terms of Bible translation, the Ethiopic version is the only one that has preserved the book of Enoch, which has some impact on Jewish traditions and NT theology, as well. Jude 14-15, for example, explicitly quotes Enoch 1:9. The book of Enoch also enjoyed high esteem among patristic writers. Clement of Alexandria, Tertullian, Origen, and Augustine supposed the book to be a genuine work of the patriarch. Later on, this book lost credibility and ceased to be quoted. Nonetheless, modern exegesis has underscored its importance for the understanding of NT theology (e.g., the son of man figure, apocalyptic literature, etc) (Charles 1893; Charlesworth 1985). It is worth noting that the biblical transactions in Ethiopia did not start with the Ge'ez translations, but go way back to the OT and NT periods (see the story of the Queen of Sheba in 1 Kgs 10:10-13 and $2 \mathrm{Chr}$ 9:1-12, and that of the Ethiopian eunuch in Acts 8:26-40). Nonetheless, the Scripture movement that penetrated North Africa as far as the corn of Africa did not penetrate Sub-Saharan Africa. The latter had to wait for the missionary era.

In a perspective of reconstruction hermeneutics, the history of early Bible translations happens to be part of the ongoing process of collection and critical restoration of biblical 
source texts. Scholars still see the Alexandrian text as the best possible representative of the original text, but much more needs to be done to determine the nature of the original text and its relation to the autographs (Petzer 1994:35-6; Omanson 2006:21*). To paraphrase H. D. Betz, reconstruction is what NT (or biblical) scholarship is all about. The NT (or the Bible) itself is the result of reconstruction. The NT (or the Bible) has been reconstructed from thousands of manuscripts and fragments, a process that still continues (Betz 2001:6). Consequently, a reconstruction paradigm challenges current and future African biblical scholars together with other colleagues to engage in textual criticism and honour the long tradition of exceptional Scripture transmissions on the continent.

\subsection{Translations during the Missionary Era (XV-XXI)}

According to Phil Noss (1998:75), "it was the Missionary Era that brought Scripture translation to the languages south of the Sahara Desert". The very first Scripture translation is certainly the Lord's Prayer in Kikongo, published in the Jesuit Fathers' Doctrina Christiana in San Salvador (Loanda, Angola) in 1624. The Kikongo language is spoken in Angola, Congo and DRCongo. It is likely that this translation was based on a Portuguese Bible. About two centuries later, the gospel of Mark became the first book of the Bible to be published in the Bullom language of Sierra Leone (Liberia) in 1816. The first complete Bible appeared in the Malagasy language in 1835, nineteen years after the Bullom gospel of Mark. Since the nineteenth century, Scripture translation has continued virtually unabated across Africa: "In terms of languages and translators, it is undoubtedly at its height today" (Noss 1998:75). However, most Bible translations in Africa represent translations of translations:

It is interesting to note that most of the existing translations in Africa were not based on the original language source texts, i.e. the Hebrew, Greek and Aramaic original source texts, but on other translations in the major languages of the colonial powers. These are so to speak translations of translations! (Mojola 2002:206-7)

What is wrong with translations of translations? This question might raise others such as: What to translate? Who is translating? For whom? Why translate? How to translate? Answers to these questions need to address respectively issues pertaining to the nature of the source text, identity of the translators, the needs and the power of the target audience, reasons for translating, as well as principles and procedures of the translations. Answering these questions will ultimately help find out whether it is right or wrong to have translations of translations. For example, a translation project sponsored by UBS (United Bible Societies) is generally expected to respond to these questions in the following ways: The source text has to be in the original source language (Hebrew, Aramaic, and Greek), such as some few cases that include "The Gospels of Matthew and John in the Ga Language," 1843; "Afrikaans Bible," 1933; "Swahili Habari Njema Bible" 1995, "Malagasy Common Language Bible" 2003. Translators (male and female) 
are to be native speakers of the target language and well-trained in biblical exegesis. The target audience is to be the local community of native speakers, especially Christians but also non-Christians. Though a Bible translation obviously aims at taking part in the mystery of proclaiming the reign of God, it is often driven by particular goals (an easy understanding of the Scripture by the majority, literary or liturgical renderings, etc). Once the reasons and goals have been specified, then methodological issues can follow logically. Functional equivalence is recommended for a translation project that is more interested in an easy yet faithful understanding by the majority of the target audience. These requirements can be considered as a summary of Bible translation ethics in UBS, at least in light of translation principles laid down by Eugene A. Nida and Charles Taber (1969; see also Wilt 2003). Consequently, it seems that there is something wrong with many UBS Scripture translations in Africa, as they are based on other translations, contrary to UBS policy that recommends the source texts to be those of the biblical original languages. To redress this situation, translation workers will need to be at the cutting edge (Mojola 2002:212).

Given the above description, it seems that there is a need for reconstructing UBS Scripture translation practices in Africa, as far as the nature of the source text is concerned. However, before embarking on exploring how such reconstruction can be done, it is worth examining the raison d'être of such endeavour. Why should African translators bother to use original source texts now or invest in textual criticism? This question sounds legitimate if we known that even some early Christians on African soil used to read the Scripture not only from a translation (e.g., LXX), but also from translations of translations, e.g., some Old Latin and Coptic versions which were based on the LXX.

One of the historical reasons that these early Africans felt uncomfortable with translations was of an apologetic nature. Jewish people ridiculed Christians for arguing on the basis of translations instead of engaging with the original sources. A second reason might be heterodox or heretical interpretations of the Scripture among Christians, which in some cases were the result of translations based on biased secondary sources. To avoid both external and internal attacks and misunderstandings, the early African Christians resolved to revise or to translate Scriptures using original source texts (cf. revisions of the Old Latin and Vulgate translation and its revisions). Are today's African Christians on safer grounds in terms of external and internal misinterpretations, suspicions and attacks, in which case they may comfortably make use of their translations of translations? Suspicions come into play because many readers, rightly or wrongly, assume that any translation done on a secondary source is critically unreliable, especially when the "original" source is available. Let us illustrate this point with a case from South Africa:

The first attempt to translate the Gospels and Psalms from the State Bible met with such adverse criticism when it appeared in 1922, that it was decided to start a completely new translation from the original languages (Hermanson 2002:8-9). 
Would not the fact of insisting on African translators to master original biblical languages and exegesis appear as perpetuating a colonising ideology, since these parameters have been put in place by Westerners? (Dube 2001:152). When an "original" source text is available, it appears more colonial and degrading to depend on secondary sources in translating Scriptures in Africa. A Lingala Bible, for example, will make a unique contribution to the post-colonial understanding of the Scriptures if it strives to mediate meanings from "original" source texts. If that Lingala Bible is a translation of a French Bible, for example, then consciously or unconsciously it will be colonising the mind of the reader with French concepts rather than those of "original" source texts. While communicating Scriptures through French concepts might be appropriate for French people, it may not be the case for the Bangala or for other Lingala speakers. This does not mean that a Lingala speaker should not read a French Bible. He or she can use it more critically as another secondary source, which ultimately has similar values and challenges as the Lingala one, as long as both translations are made from the same "original" texts. Therefore, a secondary source would not stand as a mirror for allowing another secondary text to access the "original" text. This is a way of emancipating one secondary source from the domination of another secondary source.

The majority of African Bible translations of modern time (since the fifteenth century until now) are translations of translations. This practice needs to be reconstructed in order to produce revisions and new translations that are based directly on "original" biblical languages. In UBS circles, this policy exists but it just needs to be reinforced in Africa.

\section{Conclusion}

Viewed from the perspective of the Kinshasa school of theology, reconstruction hermeneutics started with the philosopher and theologian Thiamalenga in 1981. It was taken up by SECAM in 1984-1985, then by AACC in 1990-1991, and more extensively advocated by Villa-Vicencio (since 1992), Kä Mana (since 1993), Jesse N. K. Mugambi (since 1995), and others. Reconstruction is about building better societies and Christian communities in Africa with respect to politics, economy, culture, ethics, aesthetics, spirituality, and ecumenism. Since the very beginning of the history of documented Scripture presence on the continent (cf. the LXX), Africa has played a significant role in accommodating and translating the "original" source texts. Notwithstanding this honourable tradition and that of UBS policy, which also recommends that translations be made from the "original" sources, many modern Bible translations in Africa represent translations of translations.

In the process of linking Bible translation in Africa and reconstruction hermeneutics, this article has argued that the former can benefit from the latter in two ways, namely, a greater awareness that reconstruction is what the Bible and its translation are all about, and translations of translations need to be replaced by translations of the "originals." 
Implementing this policy of translating from the "originals" would also count as a specific contribution from African Bible translators to strengthen the process of reconstruction hermeneutics. At the same time, the present article has shown how beneficial it would be to link Mugambi's reconstruction hermeneutics with some contributions from the Kinshasa school of theology, as well as with Villa-Vicencio's contributions. While Mugambi argues for social reconstruction from intellectual perspectives (descriptive, prescriptive, prospective and postulative activities), the Kinshasa school of theology can be credited for having provided more philosophical and theological grounds for a reconstruction paradigm (cf. Tshiamalenga and Kä Mana). In addition, Villa-Vicencio's contribution insists on nation-building by empowering the poor politically and economically through a democratic system and a just economy.

\section{BIBLIOGRAPHY}

AACC (All Africa Conference of Churches). 1991. The church of Africa. Towards a theology of reconstruction. Nairobi: AACC.

Aland, Barbara \& Joël Delobel (editors) 1994. New testament textual criticism, exegesis, and early church history. A discussion of methods. Kampen: Kok.

Betz, Hans D. 2001. Remarks of the SNTS President. In Interpreting the new testament in Africa, edited by Mary Getui et al., 5-8. Nairobi: Acton.

Bogaert, Pierre-Maurice. 1996. L'importance de la Septante et du 'Monacensis' de la Vetus Latina pour l'exégèse du livre de l'Exode (chap. 35-40). In Studies in the book of Exodus. Redactionreception-interpretation, edited by Marc Vervenne, 399-428. Leuven: University Press.

Bujo, Bénézet \& Juvénal Ilunga-Muya (editors) 2003-2006. African theology. The contribution of the pioneers. 2 Vols., Nairobi: Paulines.

Charles, Robert Henry. 1893. Book of Enoch. Translated from Prof. Dillmann's Ethiopic Text. Oxford: Clarendon Press.

Charlesworth, H. James. 1983. The old testament pseudepigrapha and the new testament. Prolegomena for the study of christian origins, Cambridge: Cambridge University Press.

Cilumba, Antoine N. Cibumba 2001. Wunder, glaube und leben bei Johannes. Eine exegetischhermeneutische studie am beispiel von Joh 3 im hinblick auf die inkulturationsaufgabe. Bonn: Borengässer (Arbeiten zur Interkulturalität, 3).

Cook, J. 2005. Some Novel Developments in Septuagint Research. Old Testament Essays 18(3): 531-541.

Cronin, M. 2003. Translation and globalization. London, New York: Routledge.

Loba-Mkole, Jean-Claude. 2005. Triple heritage. Gospels in intercultural mediations. Kinshasa: CERIL; Pretoria: Sapientia.

Denaux, A. (editor) 2002. New testament textual criticism and exegesis: festschrift J. Delobel. Leuven: Sterling; Paris: Peeters.

De Saint Moulin, Léon. 1997. La perception du salut et de la libération à Kinshasa. Revue Africaine de Théologie 42:203-233.

Dedji, Valentin. 2003. Reconstruction and renewal in African theology. Nairobi: Acton. 
Dube, Musa Wenkosi. 2001. 'What I have written, I have written' (John 19:22)? In Interpreting the new testament in Africa, edited by Mary Getui et al., 145-163. Nairobi: Acton.

Ehrman, D. Bart. 1994. The use and significance of patristic evidence for NT textual criticism. In New testament textual criticism, exegesis, and early church history. A discussion of methods, edited by Barbara Aland \& Joël Delobel, 118-135. Kampen: Kok.

Farisani, Elelwani. 2004. Transformation and renewal in contemporary Africa (Rom 12:1-2). In Text and context in new testament hermeneutics, edited by J. N. K. Mugambi \& J. A. Smit, 56-82. Nairobi: Acton.

Getui, Mary N. et al. 2001. Interpreting the new testament in Africa. Nairobi: Acton.

Hermanson, E. 2002. A Brief Overview of Bible Translation in South Africa. In Contemporary translation studies and bible translation. A South African perspective, edited by A. J. Naudé \& H. J. C. van der Merwe, 6-18. Bloemfontein: University of the Free State.

Kä Mana \& Kenmonge, Jean-Blaise. 1996. Ethique écologique et reconstruction de l'Afrique. Actes du colloque international organisé par le CIPRE en juin 1996 à Batié. Yaoundé: Clé.

Kä Mana. 1994. Christ d'Afrique. Enjeux éthiques de la foi africaine en Jésus-Christ. Paris: Karthala; Nairobi: CETA; Yaoundé: Clé; Lome: Haho.

Kä Mana. 2000. La nouvelle évangelisation en Afrique. Paris: Karthala; Yaoundé: Clé.

Kä Mana. 1993. Théologie africaine pour temps de crise. Christianisme et reconstruction de l'Afrique. Paris: Karthala.

Kabasele Mukenge, André. 2005. Lire la Bible dans une société en crise. Etudes d'herméneutique interculturelle. Kinshasa: Médiaspaul.

Loba-Mkole, Jean-Claude.1999. Disclosure of the Messianic Secret in Mark 14:62? A Text Critical Response. Neotestamentica 33:113-123.

Loba-Mkole, Jean-Claude. 2005. Triple heritage. Gospels in intercultural mediations. Kinshasa: CERIL; Pretoria: Sapientia.

Loba-Mkole, Jean-Claude. 2008. History and Theory of Bible Translations. Acta Patristica et Byzantina 19:169-184.

Lust, Johan. 2002. Textual criticism of the old and new testaments. In New testament textual criticism and exegesis, edited by A. Denaux, 15-31. Leuven: University Press.

Mandela, Nelson. 1994. Long walk to freedom. Boston: Little Brown \& Co.

Manus, Chris U. 2003. Intercultural hermeneutics in Africa. Methods and approaches. Nairobi: Acton.

Matand, Jean-Bosco B. L'herméneutique de l'inculturation dans Acts 15 et Gal 2, 11-14. In Inculturation de la vie consacrée en Afrique à l'aube du troisième millénaire. Acte du cinquième colloque international, edited by J. Kalonga, 143-167. Kinshasa: Carmel Afrique.

Mojola, A. O. 2002. Bible Translation in Africa. What Implications does the New UBS Perspective have for Africa? An Overview in the Light of the Emerging new UBS Bible Translation Initiative. In Contemporary translation studies and bible translation. A South African perspective, edited by A. J. Naudé \& H. J. C. van der Merwe, 202-213. Bloemfontein: University of the Free State.

Mugambi, J. N. K. 1991. The future of the church and the church of the future. In AACC.

Mugambi, J. N. K. 1995. From liberation to reconstruction. African christian theology after the cold word. Nairobi: East African Educational Publishers. 
Mugambi, J. N. K. \& Mika Vähäkangas, Mika (editors) 2001. Christian theology and environmental responsibility. Nairobi: Acton.

Mugambi, J. N. K. 2003. Christian theology and social reconstruction. Nairobi: Acton.

Mugambi, J. N. K. \& J. A. Smit (editors) 2004. Text and context in new testament hermeneutics. Nairobi: Acton.

Naudé, A. J. \& H. J. C. van der Merwe (editors) 2002. Contemporary translation studies and bible translation. A South African perspective. Bloemfontein: University of the Free State.

Ngindu-Mushete, Alphonse. 1989. Thèmes majeurs de la théologie africaine. Paris : L'Harmattan.

Nida, A. Eugene \& Charles Taber 1969. The theory and practice of translation. Leiden: Brill.

Njoroge, Nyambura J. \& Musa W. Dube (editors) 2001. Talitha Cum! Theologies of African women. Pietermaritzburg: Cluster.

Noss, Philip. 1998. Methods of Bible Translation: An Ecumenical Approach. Revue Africaine des Sciences de la Mission 8:74-95.

Omanson, Roger L. 2006. A textual guide to the greek new testament. An adaptation of Bruce M. Metzger's textual commentary for the needs of translators. Stuttgart: Bible Society of Germany.

Petzer, Jocobus H. 1994. The History of the New Testament - Its Reconstruction, Significance and Use in New Testament Textual Criticism. In New testament textual criticism, exegesis, and early church history. A discussion of methods, edited by Barbara Aland \& Joël Delobel, 11-36. Kampen: Kok.

Punt, Jeremy. 2004. Value of Ubuntu for Reading the Bible. In Text and context in new testament hermeneutics, edited by J. N. K. Mugambi \& J. A. Smit, 83-111. Nairobi: Acton.

RAT (Revue Africaine de Théologie). 2004. Ecologie et théologie africaine. Kinshasa: Facultés Catholiques de Kinshasa.

Rowland, Christopher (editor) 1999. The Cambridge companion to liberation theology. Cambridge: University Press.

SECAM (Symposium of Episcopal Conferences of Africa and Madagascar). 1985. L'Eglise et la promotion humaine en Afrique aujourd'hui. Exhortation pastorale des évêques d'Afrique et de Madagascar (Kinshasa 15-22 July 1984). Kinshasa: CEZ.

Speckman, McGlory T. 2001. The bible and human development in Africa. Nairobi: Acton.

Tamrat, Tadesse. 1972. Church and state in Ethiopia (1270-1527). Oxford: Clarendon Press.

Tshiamalenga, Ntumba. 1974. La philosophie de la faute dans la tradition luba. Cahiers des Religions Africaines 8:167-86.

Tshiamalenga, Ntumba. 1981. Les quatre moments de la recherche philosophique africaine aujourd'hui. Bulletin de Théologie Africaine 3:71-80.

Tshibangu, Tarcisse. 1960. Vers une théologie de couleur africaine. Revue du Clergé Africain 15:333-346.

Ukpong, Justin S. 1996. The Parable of the Shrewd Manager (Luke 16:1-13). An Essay in the Intercultural Biblical Hermeneutic. Semeia 73:189-210.

Uzukwu, Elochukwu E. 1996. A listening church. Autonomy in African churches. New York: Maryknoll.

Vanneste, Alfred. 1960. D’abord une vraie théologie,” Revue du Clergé Africain 15:346-352. 
Vervenne, Marc (editor) 1996. Studies in the book of Exodus. Redaction-reception-interpretation. Leuven: University Press.

Villa-Vicencio, Charles. 1999. Liberation and Reconstruction. The Unfinished Agenda. In The Cambridge companion to liberation theology, edited by C. Rowland, 153-176. Cambridge: Cambridge University Press.

Villa-Vicencio, Charles. 1992. Theology of reconstruction. Cambridge: Cambridge University Press.

Wendland, Ernst R. 2004. Translating the literature of scripture. A Literary-rhetorical approach to bible translation. Dallas: SIL International.

Wilt, Timothy. 2003. Bible translation. Frames of reference. Manchester, UK \& Northampton, MA: St Jerome. 